\title{
Educational Game Learning Japanese Language
}

\author{
Oh Daniel Kurniawan, Hendra Prasetya, Bernardinus Harnadi \\ Department of Information System, Faculty of Computer Science, \\ Soegijapranata Catholic University, Semarang, Indonesia \\ 15n20012@student.unika.ac.id, hendra@unika.ac.id,bharnadi@unika.ac.id
}

\begin{abstract}
Language and culture is an applied been possessed by every man since born. Language is a in the form of communication with each other. In daily life, communicate with the family, friend, even work also need good ability. Therefore a use of language that well and properly should be owned individuals [1]. Nihon-Goo! Is a Game made from computer for the purpose as a medium and facilitate the process increase knowledge and understanding basic vocabulary and culture in japan. After 5 times playing of one each day, game testing was conducted to 40 people and fill the questionnaire. Post-test data result shows that the game makes the player having difficulty answering the questions, but still want to play it again and again. So even though they failed to try it, they still tried again and again.
\end{abstract}

Keyword- Game, Education, Nihon-Go, Culture, Vocabulary, Japan

\section{INTRODUCTION}

Learning a foreign language especially the learning of languages japan, by doing that we were guaranteed to acquiring knowledge about the culture of japan [2]. Culture and languages has a strong links although they are two different things. The Language used by the people would reflect culture of those community actually [1]. Language is a system of developing individual psychology in an inter-subjective context [2]. Keigo is a language that is used by Japanese people in order to increase the level of listeners. Keigo can be called a language that is used to respect the other person. Keigo is often used in companies or in the world of work.

\section{LITERATUR REVIEW \\ 2.1 Language}

Language is one of the most important factors in establishing communication with other people. Without language humans will have difficulty communicating with other humans[3].

\subsection{Culture}

Culture or culture comes from the Sanskrit buddhayah which means the plural form of buddhi (mind or reason) is interpreted as things related to mind and human reason. Cultural definition according to some experts[4]. Japan is one country that has a variety of cultures, both traditional culture and modern culture or better known as pop culture[5]. Culture is the whole of skills (customs, morals, arts, sciences, etc.)[6]. That humans have as subjects of society From the point of view of anthropology culture is understood as a system of life, way of life, behavior[7]. From this definition it can be concluded that culture is all things that are the work of human creation as the subject of society. Included in this case is the language which is the result of human creation, used by humans, and passed down from generation to generation[8]. Culture is synonymous with the ways of a human group (the ways of a people). So that it can be said that the way of life of the Javanese is Javanese culture, as well as the ways of life of Japanese people can be matched with Japanese culture[9]. That is because cultural value is a concept of something that exists in the minds of most people who are considered valuable, valuable, so that it can function as a guide that gives direction and orientation to the lives of the citizens of these communities[10]. 


\subsection{Historical of Japanese Language}

Japanese or Nihongo(日本語) is a national language from Japan that is used daily by Japanese people. Japanese has a very close relationship with the surrounding countries, one of them is China. China has had the influence of language and culture on Japan in the past, therefore kanji from Japan are similar to Chinese hanzi but have different sounds[8]. Japanese people take part of Hanzi and then make it a new form, Japanese letters. to finally become three Japanese letter models, namely: kana (hiragana, katakana, and kanji).

\subsection{Story of Hiragana (平仮名)}

Hiragana letters (平 仮 名) represent from a single word, hiragana is used only to write words that are originally from Japan only.Hiragana letters are formed from modification and simplification, so hiragana letters have curved lines and are not sharp angles. In connection with this, Takebe (1998) mentions that hiragana letters began to be used in the Edo era, which at first was used by women so that hiragana is known as female letters, in Japanese it is called onnade.[5]. Hiragana letters have a total of 46 letters and include 5 vowels, namely a I u e o and the rest are syllables that line up ka, sa, ta, na, ha, ma, yes, ra, wad and one consonant and the words wo which are sometimes pronounced $\mathrm{o}[11]$.

Figure 1.1 Hiragana Strokes

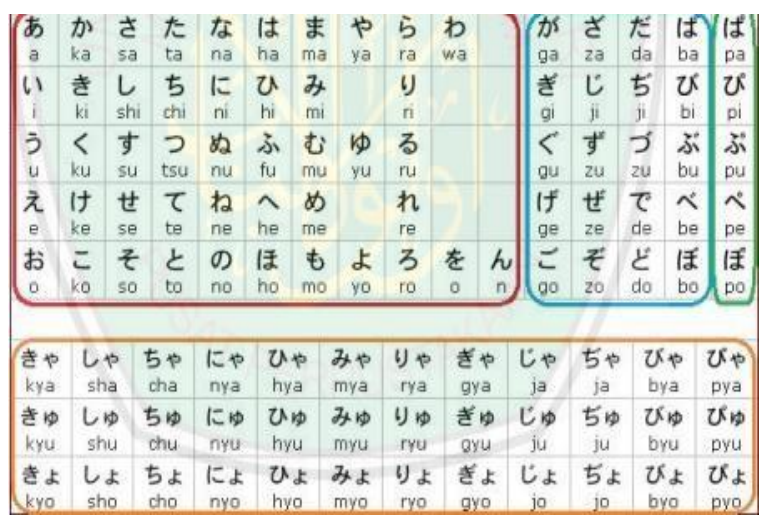

\subsection{Story of Katakana(片仮名)}

Katakana is the same as hiragana letters used for single syllables, but has different functions[12]. The letters katakana are more often used to refer to terms that are issued from foreign languages, besides that they are also used to complete a word originating from the original Japanese[13].

Katakana has taper-shaped strokes, formed from modification of kanji and takes one part of starch, so that in katakana letters there are no curved streaks like hiragana[5]. The letter katakana seems stiffer, because each streak is sharply angled which makes it called a male letter.

Figure 1.2 Katakana Strokes

\begin{tabular}{|c|c|c|c|c|}
\hline ア (阿) & 1 (伊) & ウ (宇) & I (江) & 才 (於) \\
\hline 力 (加) & キ (幾) & ク (久) & ケ (介) & $\exists$ (己) \\
\hline + (散) & シ (之) & ス (預) & 七(世) & ソ (曾) \\
\hline 夕 (多) & f (千) & ツ (川) & $\bar{\tau}$ (天) & 卜 (止) \\
\hline † (奈) & $=(Z)$ & 又 (奴) & ネ (斾) & , (乃) \\
\hline 八 (八) & 七 (比) & ᄀ (不) & へ (部) & 木 (保) \\
\hline マ (末) & ミ (三) & A (车) & x (女) & $\mp$ (毛) \\
\hline ヤ (也) & & ב (由) & & $\exists$ (与) \\
\hline ラ (良) & リ (利) & ル (流) & レ (礼) & 口 (呂) \\
\hline ワ (和) & ン (尔) & & & \\
\hline
\end{tabular}

\subsection{The Historical of Kanji (漢字)}

Historically, the kanji letters were letters originating from China, and entered Japan

Title

around the 4-5 century which numbered around 50,000 kanji. Then some of the starches were developed into hiragana and katakana letters[14]. Kanji is a type of letter used in Japanese and has its own characteristics that are different from hiragana and katakana. The way to read starch and its writing has its own meaning, therefore starch is referred to as a complicated and difficult letter to learn, however, starch is one of the most important components in Japanese[15]. 


\section{METHOD}

\section{Research Questions}

- How to design the Nihon-Goo game! which can be used as an educational tool to add insight into Japanese culture and language?

- How to create a process of learning Japanese Language and Culture that is easy to learn by teenage students through games?

- How to test the Nihon-Goo game! so that it can be accepted as an educational tool to add insight into Japanese culture and language?

\section{Research Objective}

- Know how to design the Nihon-Goo game! As an educational tool to increase the knowledge of Japanese culture and language.

- Knowing how to create a learning process of Japanese Language and Culture that is easy to learn with games as a medium.

- Know how to test the Nihon-Goo game! In order to be accepted as an educational tool to broaden Japanese culture and language.

\subsection{Flowchart}

\section{Figure 2.1 Flowchart}

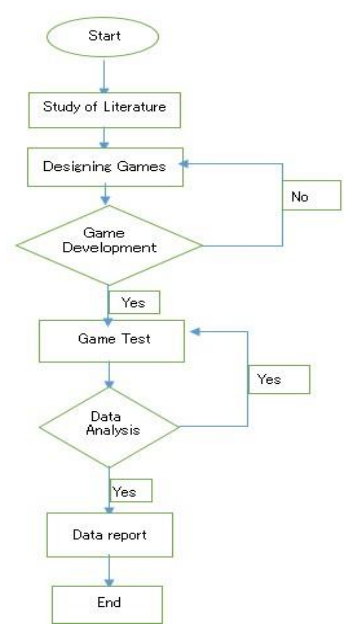

It Started with collecting data. Game design is under sketch and sounds chosen also several assets created will be used for the game. After the game is completed, then it will be tested to some beta tester. If there is a bug or error, it will be re-checked and fixed.

\subsection{Collecting Data}

There were 2 steps of collecting data. The first one was collecting data for button choice, the button choice would be used for answering the right answer. Include the several phrases which used to increases the acknowledgement the player before playing the game. The Second one was collecting data for game design by doing survey or pre-test. The subjects are 40 people either male or female and average age 22 years old.

Before making the game, the author conducted a pre-test survey in advance for several students aged 16-22 years with the aim of getting information and descriptions and their responses regarding learning Japanese Language and Culture through Games as a media.

The interview process was an unstructured interview, which was to gather several respondents in one place and ask some spontaneous questions. The answer to the question is that they like the game that is used as a learning media for Japanese language and culture because learning to memorize basic Japanese letters for them is very difficult because of the different letters of the alphabet between two countries.

The desired gameplay is the translation of a vocabulary, writing the name of the person in katakana, and memorizing the basic letters and some simple kanji accompanied by the sound of the pronunciation.

Besides learning foreign languages, especially Japanese, are classified as subjective and important for certain groups who wish to continue their studies to a higher level of education and work in Japan.

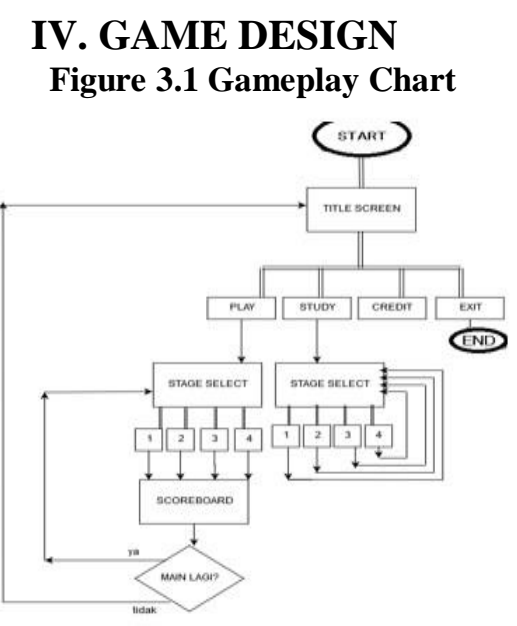


This is the gameplay chart which control all the objectives in the games. There are 4 stages which each stage has different difficulty.

Figure 3.2 Preview Game Level 1

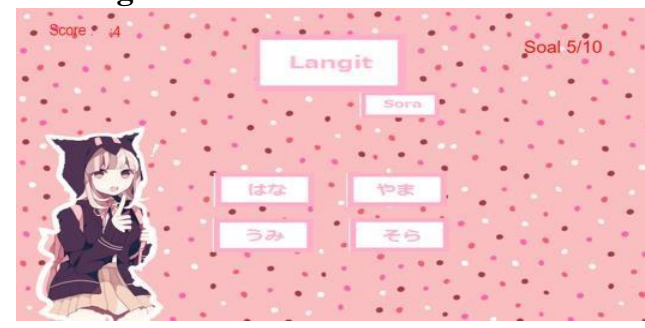

Preview stage learn hiragana letters. in this case players are required to answer one of the four alternative answers. Questions have been written on the screen and a guidance box is provided

Figure 3.3 Preview Game Level 2

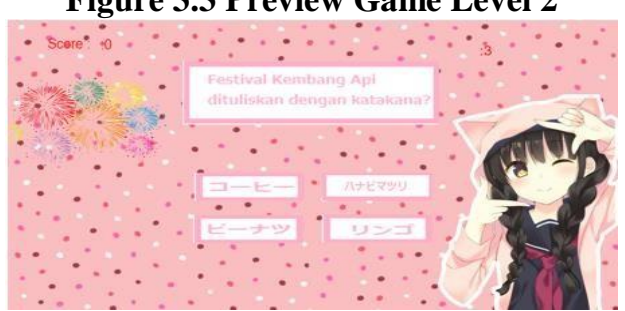

In this case seems similar with stage one, stage 2 have four alternative answer with a culture question and a hint at the left corner to help player.

Figure 3.4 Preview Game Level 3

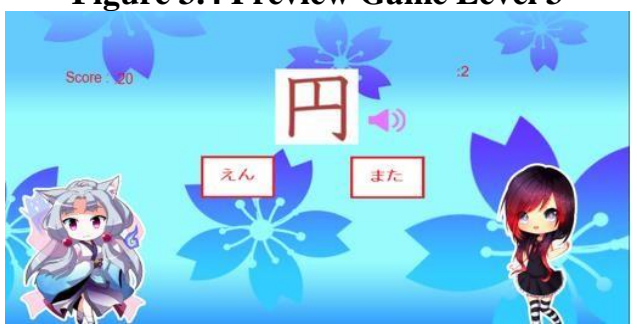

The third was kanji. Player must be know what way to say the kanji. A hint served by clicking the bell's icon.

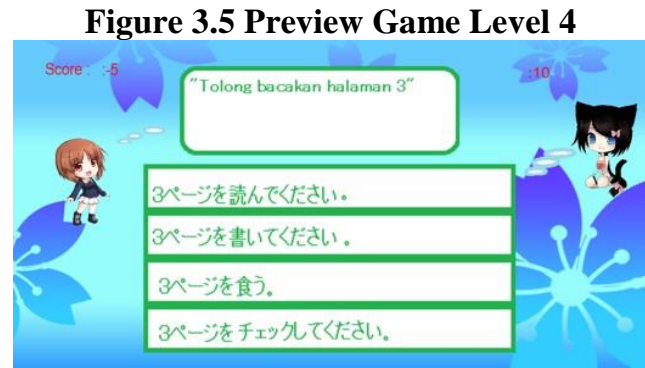

This is the last stage which contains a sentences that player must choose whether a, $\mathrm{b}, \mathrm{c}$, or d answer.

\section{RESULTS AND DISCUSSION}

\subsection{Post-Test}

The subject for this test are 40 people either female or male with average age between 16 until 22 years old and already testing Nihon-Goo! Game.

After the game is finished, the hypothesis is built to predict whether the game is NihonGoo! able to convey learning Japanese Language \& Culture. The following hypothesis is built:

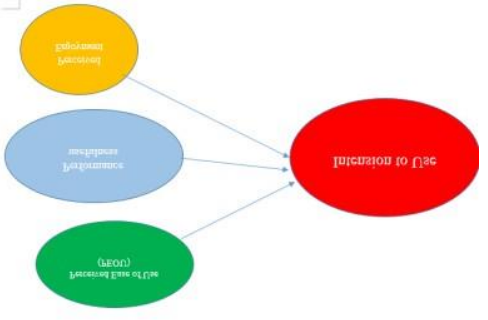

Figure 4.1 Variable Hypothesis

H1: The process of learning to teach Japanese Language and Culture will be easier and more interesting by using the Nihon-Goo Game!

$\mathrm{H} 2$ : Japanese Language and Culture learning activities will be more useful if you use the Nihon-Goo Game!

H3: People's response about learning Japanese Language and Culture will be more fun if you use the Nihon-Goo Game!

Table 4.2 Analysis Factor

\begin{tabular}{|l|r|r|r|r|}
\hline \multirow{2}{*}{} & \multicolumn{5}{|c|}{ Rotated Component Matrix ${ }^{\mathrm{a}}$} \\
\cline { 2 - 5 } & \multicolumn{1}{|c|}{ Component } \\
\hline PEOU1 & -.121 & -.070 & .796 & .109 \\
PEOU2 & .411 & -.209 & .601 & -.144 \\
PEOU3 & -.195 & .216 & .667 & -.044 \\
PU2 & .106 & -.053 & .104 & .812 \\
PU3 & -.025 & .057 & -.104 & .813 \\
PE1 & .871 & -.036 & -.233 & -.061 \\
PE2 & .829 & -.264 & .103 & .166 \\
PE3 & .850 & -.205 & -.090 & .056 \\
I1 & -.300 & .716 & .026 & .154 \\
I2 & .003 & .880 & .054 & -.116 \\
I3 & -.181 & .813 & -.067 & -.003 \\
\hline
\end{tabular}

Extraction Method: Principal Component Analysis.

Rotation Method: Equamax with Kaiser Normalization.

a. Rotation converged in 5 iterations. 
It can be seen that the PU1 variable indicator converges with other PU indicators but does not group with other PU indicators so that PU1 is dropped

Table 4.3 Reliability Statistic

Reliability Statistics

\begin{tabular}{|c|c|c|}
\hline Variabel & $\begin{array}{c}\text { Cronbach's } \\
\text { Alpha }\end{array}$ & $\begin{array}{c}\text { Internal } \\
\text { Consistency }\end{array}$ \\
\hline PEOU & .467 & Unacceptable \\
\hline PU & .540 & Poor \\
\hline $\mathrm{PE}$ & .862 & Good \\
\hline । & .766 & Acceptable \\
\hline
\end{tabular}

It Shows on Table 4.3 about level of Internal Consistency between Poor to Good except for PEOU variables that have an Unacceptable level of Internal Consistency.

Table 4.4 Correlation Values

\begin{tabular}{|c|c|c|c|c|c|c|c|}
\hline & A & $G$ & EDU & APEOU & APU & APE & Al \\
\hline A & 1 & .097 & $.331^{\circ}$ & -014 & .169 & $.515^{\prime \prime}$ & .137 \\
\hline$G$ & .097 & 1 & -167 & .244 & $.358^{\circ}$ & -106 & .125 \\
\hline EDU & $.331^{\circ}$ & -167 & 1 & .046 & -093 & .045 & .089 \\
\hline APEOU & .014 & .244 & .046 & 1 & .023 & .068 & .024 \\
\hline APU & .169 & $.358^{\circ}$ & .093 & .023 & 1 & .034 & .028 \\
\hline APE & $.515^{\prime \prime}$ & -106 & -045 & -.068 & .034 & 1 & $-369^{\circ}$ \\
\hline Al & .137 & .125 & -089 & -024 & .028 & $-369^{\circ}$ & 1 \\
\hline
\end{tabular}

In conclusion, $P E$ has a negative correlation at I, in other words if the less pleasure is found, then the desire to play the game is very large. Conversely, if the pleasure found is very large, then the desire to use the game is very small. It is estimated that the possibility of respondents having difficulty answering the questions, but still want to play it again and again. So even though they failed to try it, they still tried again and again.

\section{CONCLUSION}

Nihon-Goo Game! designed using the ame engine construct2, each level containing varied learning and accompanied by sound pronunciation of each basic letter and explanation of some traditional Japanese cultures.

The learning process of Japanese Language and Culture that is easy to learn can be created by playing the Nihon-Goo Game! because it contains learning material in the form of simple basic letters.

From the results of testing the NihonGoo Game! indicates that there are no variables that correlate with the desire to continue playing the Nihon-Goo game! except for the Enjoyment variable even though it is negatively correlated.

\section{REFERENCES}

[1] Nostrand, "Pengertian budaya menurut para ahli," 2019. [Online].

Available:

www.zonareferensi.com/pengertiankebudayaan. [Accessed: 20-Sep-2007].

[2] B. Adams, "Pengertian Bahasa menurut para ahli dan secara umum." [Online]. Available:

http://www.zonareferensi.com/pengerti an-bahasa.

[3] Renariah, "Bahasa Jepang dan karakteristiknya," J. Sastra Jepang Fak. Sastra Univ. Kristen Maranatha, vol. 1, no. 2, pp. 1-16, 2002.

[4] A. Fitria, "Game Kyuzi Goes to Japan untuk Pembelajaran Kosakata Bahasa Jepang menggunakan Metode Fuzzy Stage machine (FuSM) Sebagai Perilaku Non-Playable Character (NPC)," 2014.

[5] N. Pada, P. Huruf, H. Siswa, K. X. Sma, K. Bhayangkari, and D. A. Permithasari, "HIKARI : E-Journal Pengajaran Jepang Universitas Negeri Surabaya HIKARI : E-Journal Pengajaran Jepang Universitas Negeri Surabaya," E-Journal Pengajaran Jepang Unesa, vol. 1, pp. 1-7, 2014.

[6] R. Brisling, "Pengertian Budaya Menurut Para Ahli." [Online]. Available:

www.zonareferensi.com/pengertiankebudayaan/.

[7] S. Pendidikan, B. Jepang, J. B. Asing, U. N. Surabaya, and M. Litt, "Pengembangan Media Goi Game Berbasis Web Pada Pembelajaran Kosakata Bahasa Jepang Buku Nihongo 1 Di Sma," E-Journal Unesa, vol. I, pp. 2-4, 2013. 
[8] O. A. Venus and L. Helmi, "Budaya Populer Jepang di Indonesia: Catatan Studi Fenomenologis Tentang Konsep Diri Anggota Cosplay Party Bandung," J. ASPIKOM, vol. 1, no. 1, pp. 71-90, 2010.

[9] N. Andari, "Budaya Indonesia Dan Jepang (Tinjauan Tradisi Penamaan Dan Gerak Isyarat," Fak.Sastra Untag Surabaya, vol. 9, no. 2, pp. 22-29, 2009.

[10] W. Marlianti, "Game Edukasi 'Kabayan Nyunda' Berbasis Android,' J. Chem. Inf. Model., pp. 1-18, 15AD.

[11] M. D. Burress and J. M. Peters, "Collaborative Learning in a Japanese Language Course," SAGE Open, vol. 5, no. 2, p. $215824401558101,2015$.

[12] K. Kosakata, B. Jepang, H. Elian, Y. Rosliyah, and D. Prasetiani, "Journal of Japanese Learning and Teaching," vol. 4, no. 1, pp. 10-13, 2015.

[13] M. J. Semita, Cara Mudah\&Praktis Belajar Bahasa Jepang. Yogyakarta: Pusat Kajian Bahasa, 2017.

[14] S. I. Trahutami, "Nilai Sosial Budaya Jepang Dalam Peribahasa Jepang yang Menggunakan Konsep Binatang," vol. 5, no. 1, 2015.

[15] L. M. Rasiban, "Kanji Learning Strategies through the Knowledge of Kanji History," Underst. Basic Kanji, vol. 82, pp. 132-138, 2018. 